\title{
NSF International Conference on Social and Cultural Nexus of Science and Technology Development (2019)
}

\author{
Sirimevan Colombage* \\ Emeritus Professor in Economics, The Open University of Sri Lanka, Nawala, Sri Lanka. \\ Chairman, Working Committee on Social Sciences, National Science Foundation, Colombo 07, Sri Lanka.
}

Currently, the world is undergoing an age of unprecedented technological progress exerting dramatic influences on individual lifestyles, social relations and natural environment. Undoubtedly, Science and Technology (S\&T) have proven to be the key drivers of sustainable socioeconomic progress in many parts of the world in recent decades.

However, there are serious concerns about the harmful effects of modern technology on society. Such effects include cyber security risks, threats to personal well-being and safety, increasing sense of social isolation, relational problems, cultural breakdowns, technology addiction, environmental hazards and threats to wildlife.

In order to mitigate such risks, technology needs to be integrated with societal needs. Yet, this premise does not seem to be fully recognised in policymaking or in empirical research. Social, psychological and cultural factors may facilitate or restrain S\&T development, in particular social and cultural contexts. Traditional cultural values, for instance, could hinder transfer of technology, use of technology and spread of technological culture. While economic benefits of modern technology are quantifiable and well known, the socio-cultural interactions with technology are not so obvious.

It is in this backdrop that the National Science Foundation (NSF) hosted the International Conference on "Social and Cultural Nexus of Science and Technology
Development (SCST)" in Colombo on 3-4 October 2019. This conference, which was organised by the Working Committee on Social Science of NSF, provided a platform to scholars in different disciplines to exchange their research findings on the impact of fast developing S\&T on society, and to draw policy conclusions.

\section{Inaugural addresses}

Welcoming the Conference participants, Dr A. M. Mubarak, Chairman of the NSF, highlighted that the Fourth Industrial Revolution (4IR), fusing the physical, digital and biological worlds, is certain to alter the way humans live, work and relate to one another. Dramatic technological advances are already happening in different fields, including robotics, automation, nanotechnology, quantum computing, biotechnology, 3D printing and big data analytics. This International Conference, therefore, was timely and it gave an opportunity to a corpus of multidisciplinary scholars to present their work.

Prof. Ananda Jayawardane, Director General of the NSF, emphasised that notable differences in technological adoption in developing and developed countries can be attributed not only to technological and economic factors, but also to socio-cultural factors. Therefore, understanding the complex relationships between scientific and technological progress and sociocultural factors is critically important for policymakers and technocrats alike for sustainable development.

"Corresponding author (sscol@ou.ac.lk)

This article is published under the Creative Commons CC-BY-ND License (http://creativecommons.org/licenses/ by-nd/4.0/). This license permits use, distribution and reproduction, commercial and non-commercial, provided that the original work is properly cited and is not changed anyway. 


\section{Keynote speech}

The keynote speech themed "Prioritizing Planet, People and Profits-Health and Environment" was delivered by Prof. Bhushan Patwardhan, Vice-Chairman of the University Grants Commission, India. While referring to Gandhian Engineering, which is "all about getting more (performance) from less (resources) for more (people) and not just for more profits", he questioned "for whom scientists are working-business or people?".

Quoting examples from his own field, medical science, Prof. Patwardhan stated that virtually all pathogens regarded as "new" existed previously as well. Emergence of "new" agents of diseases has generally resulted not from changing pathogens but from social conditions and environmental changes that have created new environmental pathways for pathogens. It was noted that doctors did not control cholera or typhoid in the West, but nutritious food, safe-drinking water and pasteurized milk did this for them.

Prof. Patwardhan expressed his concerns about the "medicalisation" of the society and exorbitant profit-making by pharmaceutical manufacturers. He emphasised the fact that businesses and profits of pharmaceutical industry linked to sufferings and agony of people are not sustainable. According to Mahatma Gandhi, "The earth provides enough to satisfy every man's need, but not any man's greed".

Concluding his insightful speech, Prof. Patwardhan emphasised that the "Pancha Sila" preached by Lord Buddha shows the righteous pathway for sustainable living.

\section{Plenary speeches}

The two plenary speeches on "Cultural Embeddedness of Science" and "Social and Economic Context of S\&T Development" were delivered respectively by Prof. Amita Singh, Jawaharlal Nehru University and Prof. P. Kanagasabapathi, Council Member, Indian Council of Social Science Research (ICSSR).

Prof. Singh noted that while most Asian countries are making efforts to move into an intensive scientific society to reap the benefits in a competitive global mainstream production and progress, attention should be drawn to the dangers and the wastefulness of inappropriate science that may turn counterproductive. Prof. Kanagasabapathi emphasised that policy makers must provide inducements to local societies to improve their natural tendencies to innovate in diverse technical and engineering fields.

\section{Technical sessions}

The technical sessions of the conference comprised of oral and poster presentations. There were seventeen oral presentations categorised under seven sub-themes, namely: (a) Education and S\&T Development, (b) Social and Economic Context of S\&T Development, (c) Risks and Benefits of Modern Technology, (d) State Policy and S\&T Development, (e) Role of Private Sector in Development, (f) Media and S\&T Development, and (g) Public Understanding of Science and Scientific Literacy. The poster presentations covered: (a) Virtual Learning Environment in Higher Education, (b) Contribution of Newspapers in Disseminating S\&T Knowledge among the Public, (c) Blended Learning Approach, and (d) Coastal Setback Policy.

Going beyond pure economic considerations, the presentations of the conference covered a wide spectrum of S\&T-related issues, including health hazards, indigenous knowledge, home-grown technology, smartaging society, gender imbalances, scientific literacy, technology-based education, virtual learning, ecofriendly agriculture, green adoption in manufacturing, predisaster warning, S\&T policies, ethical responsibilities and bio-degradable waste management.

\section{Renewal of the MOU between NSF and ICSSR}

Considering the close nexus between technology and society, as amply demonstrated during the two-day conference, the NSF recognises the need to provide opportunities to local social scientists to partner with their counterparts in neighbouring countries and elsewhere to enhance their research capabilities and to exchange views on country-specific issues.

In parallel with the International Conference, the NSF renewed and broadened its Memorandum of Understanding (MOU) with the Indian Council of Social Science Research (ICSSR), which was originally signed in 2014. Capacity building among young social scientists in both countries, among other items, is prioritised as a major activity under the MOU. It was also agreed to pursue collaborative research in critical areas, including cultural relations, environment, trade and investment cooperation, social challenges, demographic transition, macroeconomic policies, global financial markets, education and health, internal and external challenges, sustainable development in aspiring societies and governance.

\section{Policy dialogue}

The Policy Dialogue of the Conference, themed "Role of Education in Promoting S\&T in Sri Lanka" conducted 
by a panel of experts led by Prof. Siri Hettige, focused on the challenges and prospects pertaining to education in the context of S\&T development.

While appreciating the efforts taken by the Sri Lankan education authorities to shift education towards science, technology, engineering and mathematics-collectively known as STEM disciplines-to prepare the students for a competitive knowledge-based economy, concerns were expressed by many participants with regard to numerous disadvantages in neglecting liberal arts streams such as languages, literature, history, philosophy, drama, music and dancing, which are vital for individual flourishing and social well-being. Hence, adoption of multidisciplinary curricula crossing the traditional subject boundaries was emphasised during the deliberations. It also came to light during the discussion that the Indian education authorities are now moving from the currently fashionable notion of "human resources development" towards conventional "education".
Broadly, there was consensus among the conference participants that the education system in Sri Lanka needs to be revamped rationally so as to meet the emerging socioeconomic challenges at the doorsteps of the Fourth Industrial Revolution, while striking a balance between human capital development and socio-cultural values.

\section{Way forward}

The conference, which brought together academics, researchers and policymakers from different fields, highlighted the need to orient S\&T development towards societal needs. This could be considered as a pioneering step taken by the NSF, as the socio-cultural dimensions in S\&T are somewhat neglected in academic research as well as in policy making at the global level.

The NSF is expected to issue a policy brief covering the proceedings of the conference for the benefit of academics, researchers, policymakers and the general public. 